Т. М. Клименко, Т. В. Сандуляк, О. А. Сердцева, О. Ю. Карапетян, А. М. Закревський Харківська медична академія післядипломної освіти

\title{
МОДЕЛЮВАННЯ КЛІНІЧНИХ СИТУАЦІЙ - СТАНДАРТ ПРОГРАМИ СИМУЛЯЦІЙНОГО НАВЧАННЯ ЛІКАРІВ НА КАФЕДРІ НЕОНАТОЛОГІї
}

\author{
T. M. Klymenko, T. V. Sanduliak, O. A. Serdtseva, O. Yu. Karapetian, \\ Kharkiv Medical Academy of Postgraduate Education

\section{CLINICAL SETTING MODELING - STANDARD OF DOCTORS' SIMULATIVE LEARNING PROGRAM AT THE DEPARTMENT OF NEONATOLOGY}

A. M. Zakrevskyi

\begin{abstract}
Мета роботи - підвищити ефективність навчання лікарів за програмою первинної реанімації новонароджених шляхом моделювання клінічних ситуацій при набутті компетентності спеціалістів закладу родопомочі працювати в командах, акцентувати увагу на важливості симуляційного навчання дорослих для оволодіння алгоритмами надання дихальної підтримки та реанімаційної допомоги новонародженим у пологовій залі.

Основна частина. У статті розглядаються сучасні принципи та методика симуляційного навчання лікарів шляхом моделювання клінічних ситуацій та відповідне матеріальне і методичне забезпечення виконання практичних навиків первинної реанімації новонароджених згідно з вимогами ILCOR 2015 р.

Проведені анкетування та оцінка результатів пре-тесту 200 слухачів та аналіз літературних джерел і власного досвіду роботи за методикою симуляційного навчання з використанням контрольних листів виконання практичних навичок і відеоспостереження.

Методика симуляційного навчання значно розширила можливості навчального процесу та показала її ефективність у перинатальних центрах, але в пологових будинках регіону спеціалісти ще не охоплені необхідним рівнем навчання і показують гірші результати роботи по забезпеченню дихальної підтримки та реанімації новонароджених.

На кафедрі неонатології ХМАПО проведена оцінка причин недостатньої ефективності навчання та роботи спеціалістів закладів родопомочі й змінена методика навчання. Використано педагогічне проектування кожної теми з моделювання клінічних ситуацій при симуляційному навчанні та набутті лікарями компетентності надання дихальної підтримки і реанімаційної допомоги, особливо недоношеним дітям, за алгоритмами ILCOR 2015 року.

Висновки. Досвід застосування моделювання клінічних ситуацій при симуляційному навчанні спеціалістів безпосередньо в закладах родопомочі дозволив підвищити ефективність навчального процесу і покращити показники роботи пологових будинків. Слухачі мають змогу отримати не лише теоретичну підготовку, а й в обов'язковому порядку оволодіти необхідними практичними навичками і вмінням роботи, що сприяє поліпшенню розуміння та засвоєння матеріалу, набуття професійної компетентності виконати вимоги ILCOR 2015 року та протоколу MO3 України “Початкова, реанімаційна і післяреанімаційна допомога новонародженим в Україні ” 2014 року.
\end{abstract}

Ключові слова: програма реанімації новонароджених; передчасно народжені діти; дихальна підтримка; моделювання клінічних ситуацій; симуляційне навчання дорослих.

The aim of the study - to increase the effectiveness of training physicians according to primary neonatal resuscitation program by simulating clinical settings when acquiring institution birth attendance competence of specialists working in teams to emphasize the importance of adult learning simulation for learning algorithms of respiratory assistance and intensive care to newborns in the delivery room.

The main body. The modern principles and methods of simulative training of doctors by modeling the clinical settings and appropriate financial and methodological support of practical skills of neonatal resuscitation as required by ILCOR 2015 are considered in the article.

The survey and evaluation of pre-test of 200 professionals and analysis of the literature and personal experience of the technique simulation studies using control sheets of practical skills and video surveillance are carried out.

Methods of simulation training greatly enhanced the educational process and demonstrated its effectiveness in perinatal centers, but in hospitals of the region specialists have not reached the required level of training and showed worse results to provide respiratory support and neonatal resuscitation.

The Department of Neonatology of KhMAPO evaluated due to insufficient efficacy studies and specialist institutions of birth attendance and changed methods of teaching. Instructional design of each topic on clinical settings modeling within simulation training and respiratory support and intensive care, provided by doctors, especially for premature babies, according to algorithms of ILCOR 2015 are used.

(c) Т. М. Клименко, Т. В. Сандуляк, О. А. Сердцева та ін. 
Conclusion. Experience with clinical setting modeling in simulation training of professionals directly at the establishments birth attendance allowed to increase the effectiveness of the educational process and improve the performance of maternity. Professionals can receive not only theoretical knowledge but necessarily acquire the necessary practical skills and ability to work that improves understanding and learning, acquisition of professional competence to fulfill the requirements of ILCOR 2015 and Minutes of Ministry of Healthcare of Ukraine "Primary, Resuscitation, and Post-resuscitation Newborn Care in Ukraine" in 2014.

Key words: neonatal resuscitation program; prematurely born children; respiratory assistance; clinical setting modeling; simulation training of adults.

Вступ. В Україні створена національна мережа перинатальних центрів, ресурсні умови яких надають можливість застосування найсучасніших підходів і методів надання первинної допомоги новонародженим, особливо передчасно народженим дітям. Для забезпечення ефективної допомоги необхідна підготовка компетентних спеціалістів неонатологів, акушерів-гінекологів і анестезіологів. На часі актуальні розробки інтерактивного командного навчання лікарів різних спеціальностей із різним практичним досвідом і стажем роботи одночасно, використовуючи реальні та моделювання навчальних клінічних ситуацій.

Американською асоціацією серця та Міжнародним погоджувальним комітетом з питань реанімації (ILCOR) у жовтні 2015 р. опубліковано нові рекомендації з реанімаційної допомоги новонародженим [1-3]. Групою міжнародних експертів на підставі пошуку, аналізу й узагальнення результатів досліджень впливу ефективності навчання спеціалістів на якість надання реанімаційної допомоги новонародженим у пологовій залі $[3,4]$ внесені нові підходи та вимоги до забезпечення фето-неонатальної адаптації, що потребувало перегляду програми і методик навчання спеціалістів на нашій кафедрі. В оновленому документі моделювання клінічних ситуацій при симуляційному навчанні спеціалістів дихальної підтримки та реанімації новонароджених залишилось як стандартний компонент проведення тренінгів $[3,4]$ і рекомендовано змінити регулярність навчання лікарів з 1 разу через кожні 2 роки на кожні 6 місяців та навчати одночасно команди з різних спеціалістів у кожному лікувальному закладі (рівень доказовості II В).

Мета роботи - підвищити ефективність навчання лікарів за програмою первинної реанімації новонароджених шляхом моделювання клінічних ситуацій при набутті компетентності спеціалістів закладу родопомочі працювати в командах, акцентувати увагу на важливості симуляційного навчання дорослих для оволодіння алгоритмами надання дихальної підтримки та реанімаційної допомоги новонародженим у пологовій залі.

Основна частина. 3 метою оцінки ефективності навчання спеціалістів за програмою первинної реанімації нами проведено анкетування 200 неонатологів, акушерів-гінекологів та анестезіологів пологових будинків, котрі пройшли навчання 5 років тому. Аналіз анкет показав, що недостатня ефективність навчання зумовлена як характеристикою слухачів, так і методикою навчання та ефективністю педагога.

Симуляція - ефективний інструмент для відпрацювання практичних навичок та командної взаємодії, але це не єдиний спосіб досягти успіху в клінічному навчанні та роботі. Навчання окремих неонатологів з різних закладів програми первинної реанімації в центрі симуляційного навчання на кафедрі само по собі не дало очікуваних результатів покращення якості допомоги новонародженим. На практиці, через різноманітні причини, не всі лікарі ретельно виконують всі протокольні вимоги надання первинної реанімації, що характерно і для персоналу закладів родопомочі $[4,5]$.

Для вивчення причин неналежного виконання наказу MO3 № 225, перед початком навчання на циклах, нами проведена експертна оцінка якості наданої допомоги за медичною документацією та анкетування 2 груп лікарів: зі стажем роботи більше 5 років і без стажу. Анкету створено у вигляді Персонального листа практичного досвіду надання первинної реанімаційної допомоги. Отримані результати опитування суттєво не відрізняються від даних у літературі [4, 5], окрім високої питомої ваги слухачів, котрі прочитали наказ, але під час роботи в закладах родопомочі рідко або не тестувались на предмет володіння вміннями та навиками надання допомоги новонародженим і не проходили практичної підготовки з даної теми для роботи в команді. Крім того, в окремих закладах, слухачі з великим стажем роботи ще продовжують миритись із недостатнім забезпеченням пульсоксиметрами з реєстрацією ЕКГ, аспіраторами меконію, катетерами для вени пуповини діаметром 5F, сучасними змішувачами та зволожувачами повітря, відсутністю манометрів для контролю тиску повітря в дихальних шляхах та приладів для капнографії або рентгенологічного контролю положення інтубаційної трубки тощо. Замість катетеризації вени пуповини для введення ліків, подекуди акушерки продовжують 
безпосередньо вводити їх шляхом пункції судин пуповини. При реєстрації протоколу проведених реанімаційних заходів не заповнюються всі графи і таблиці згідно з вимогами ILCOR 2015 року, не використовується оновлена шкала Апгар та ін.

Підготовка спеціалістів закладів родопомочі до проведення реанімації новонароджених та створення їм фізіологічних умов адаптації дихання та кровообігу в перші 2-20 хв життя залежно від морфологічної та функціональної зрілості дитини, особливо передчасно народженим з гестаційним віком 24-32 тижні, викладачами кафедри здійснюється 3 використанням програмного і ресурсного забезпечення на засадах NRP Американської асоціації серця та Американської академії педіатрії [1] і рекомендаціях European Resuscitation Council Guidelines: Resuscitation and support of transition of babies at birth [2]. Зазначені навчальні програми реанімації новонароджених включають: 1) покрокове засвоєння дидактичного курсу з 9 коротких лекцій з відео та мультимедійним забезпеченням та 7 уроків інтерактивного симуляційного навчання в парі з викладачем по засвоєнню та опрацюванню практичних навиків виконання процедур і реанімаційних заходів; 2) оволодіння алгоритмами надання допомоги згідно з гестаційним віком зрілості дитини; 3) засвоєння вміння злагодженої роботи в команді з 2-3 спеціалістів по своєчасному та ефективному виконанні необхідних реанімаційних заходів; 4) моделювання та імітація можливих клінічних сценаріїв і реальних клінічних ситуацій з щоденної практики лікарів у своїх закладах за медичною документацією, котра протокольно засвідчує дії лікарів при проведенні первинної реанімації та дає змогу оцінити ефективність наданої допомоги.

Програма забезпечена інтерактивним програмованим підручником з реанімації новонароджених, який складається з навчальних компонентів:

- Teach - вчити (когось) або Tеaching - очний процес навчання, який відбувається безпосередньо зараз: лекція, семінар, практичне заняття та заснований на особистому прикладі і досвіді викладача;

- Learn - вчити (щось); Learning - процес навчання, засвоєння знань та навичок слухачем під керівництвом викладача (тьютора) як безпосередньо, так і дистанційно, за допомогою відповідних технологій та посібників;

- Tutorial - підручник з виписаною інструкцією послідовності дій до кожного уроку та покроковим алгоритмом виконання кожної процедури з описан- ням можливих помилок та ускладнень реанімації і їх профілактики.

Досвідчені викладачі, котрі засвоїли перелічені компоненти програми навчання, в процесі роботи зі слухачами виступають в ролі Tutor - наставника, репетитора, провідника слухача чи команди спеціалістів у процесі навчання. Для ефективного вивчення матеріалу програми та засвоєння навиків і вмінь виконання необхідних процедур та алгоритмів на кафедрі створено клас симуляційного навчання, оснащений відповідним обладнанням, тренажером і манекенами. До кожного практичного навику виписані методика (еталон) виконання і створені контрольні листи виконання процедури з бальною оцінкою за якість та швидкість виконання кожного пункту еталона. Крім того, робота команди спеціалістів по виконанню алгоритму реанімації реєструється відеокамерою з наступним переглядом та аналізом виконавцями допущених тактичних і технічних помилок, біоетичних норм, оцінкою активності та злагодженості в роботі кожного члена команди і ролі викладача.

Викладачі кафедри використовують всі сучасні освітні методики навчання, оцінювання і підтримання знання та навичок з реанімації новонароджених, зокрема інтерактивне викладання матеріалу програми на лекціях та семінарах зі створенням і рішенням слухачами численних проблемних навчальних ситуацій за кожним відгалуженням алгоритму первинної реанімації у доношених та недоношених дітей; “ділової гри” для опрацювання практичних навичок; “групової динаміки” і тренінг та інтерактивну комунікацію для освоєння ролей кожного виконавця частини алгоритму реанімації при роботі в команді; “мозкового штурму” для оцінки потреби в реанімації; оцінки ефективності реанімаційних заходів за відповіддю дитини на їх проведення; оцінки причин відсутності очікуваного ефекту від проведених реанімаційних заходів, прогнозування та діагностики ускладнень; впровадження індикаторів оцінки якості надання допомоги новонародженим у пологовій залі.

При формуванні методичних розробок та планівсценаріїв проведення занять нами особливу увагу приділено дидактичному проектуванню [6], яке містить етапи конструювання змісту освіти, аналіз та прогнозування мети навчання, діагностику стану навчального процесу, конструювання навчальних матеріалів та вибір технологій навчання до кожної теми. Для інтенсифікації навчального процесу, стимулювання систематичної та самостійної роботи слухачів, підвищення об’єктивності 
оцінювання знань методики проведення заняття до кожної теми підбирали окремо залежно від досвіду роботи слухачів та ступеня володіння навиками. Для набуття компетентності і готовності слухачів надати необхідну допомогу дитині, утримання та збагачення знань, вміння використовувати отримані знання і навики, під час тренінгів команд спеціалістів, численні алгоритми надання первинної реанімаційної допомоги повторювали багато разів, що суттєво покращувало результат навчання лікарів і ефективність впровадження програми реанімації у закладі. Навчання команд спеціалістів також суттєво покращувало особисті поведінкові характеристики слухача, такі, як: уважність, концентрація на проблему для досягнення очікуваного результату, узгодженість дій та послідовності виконання реанімаційних заходів кожним членом команди, відчуття часу, ритму і темпу виконання процедури, злагодженість при виконанні необхідних заходів і розуміння дій товариша.

Основні елементи програми для викладання:

- оцінка перинатальних факторів ризику народження дитини у стані депресії;

- обгрунтування алгоритму надання допомоги;

- підготовка робочого місця;

- гігієна рук, дотримання вимог інфекційного контролю та профілактики інфекцій, зумовлених наданням медичної допомоги;

- початкові кроки забезпечення кардіо-респіраторної адаптації та фізіологічних умов догляду під час проведення процедур;

- засвоєння методик забезпечення прохідності дихальних шляхів, включаючи інтубацію трахеї для санації та для ШВЛ і санацію через інтубаційну трубку;

- оцінка характеру дихання та забезпечення ефективної вентиляції респіратором і маскою;

- проведення інтубації трахеї для починання або продовження ШВЛ;

- проведення непрямого масажу серця;

- обгрунтування використання та введення медикаментів;

- забезпечення венозного доступу, катетеризація вени пуповини;

- закінчення реанімаційних заходів та особливості їх проведення у дітей, народжених без пульсу (серцевих скорочень), та вкрай незрілих немовлят зі строком гестації до 23 тижнів;

- засвоєння алгоритмів дій при нестандартних ситуаціях та ускладненнях реанімації новонароджених у пологовій залі;
- забезпечення моніторингу стану дитини під час проведення реанімації та при наданні післяреанімаційної допомоги;

- початок проведення лікувальної гіпотермії, підготовка дитини до переведення та скерування в заклад вищого рівня медичної допомоги, де така терапія буде проведена;

- стабілізація стану немовляти перед транспортуванням і медичний супровід під час транспортування до закладу вищого рівня;

- оформлення інформованої згоди батьків на проведення реанімаційних заходів та післяреанімаційної допомоги немовляті.

Враховуючи сказане, нами вибрані методики викладання матеріалу в обох групах слухачів з урахуванням сучасної концепції навчання дорослих: характеристика груп дорослих, які навчаються; створення навчальної атмосфери на кафедрі; ефективний викладач.

Характеристику груп слухачів перед та під час навчання склали на основі спілкування з кожним лікарем, анкетування та аналізу результатів їх самопідготовки, активності у вивченні матеріалу теми та спроможності засвоїти практичні навики. Перед групою в цілому та окремо кожному слухачу поставлена мета навчання - досягнення необхідної компетентності для ефективної роботи по виконанню наказу № 225 і вимог ILCOR 2015 року.

Навчання - активний процес здобуття нових знань, вмінь та навиків, з наступним їх використанням у професійній діяльності. Зміни слухачів під час навчання мотивуються модифікацією способу індивідуального розуміння свого власного внеску в результати виконуваної роботи. Індивідуальні переконання, цінності, потреби, життєва позиція, самосвідомість, а також рефлексивні механізми креативності особистості [7], психофізіологічні механізми її адаптивної поведінки в ситуації, що потребує чітких конкретних дій [8], - все це впливає на спосіб, яким отримується нова інформація і відбуваються зміни особистості лікаря. Більшість слухачів післядипломної підготовки входить у навчальний процес з попередньо сформованою самооцінкою і самосвідомістю, а також зі “старими помилками” в практичній роботі. Вони використовують свій старий досвід прийняття рішень i розв’язання проблем у нових навчальних ситуаціях, який нерідко заважає їм засвоєнню сучасних стратегій програми, або нехтують даними доказової медицини щодо досягнення максимальної ефективності первинної реанімації. 
Психологи виявили взаємозв'язок рефлексивних механізмів з якостями особистості: життєва орієнтація, мотивація і відношення до предмета навчання, емоціонально-поведінкові особливості засвоєння матеріалу. Вчені вказують на відмінності у виявленні особистісних якостей при взаємодії різних рівнів рефлексивності з різними рівнями вербальної та невербальної креативності [7]. Слухачі з високим рівнем рефлексивності в поєднанні з високим рівнем вербальної та (або) невербальної креативності характеризуються чіткою усвідомленістю життєвих цінностей, високою мотивацією і самокерованістю, тоді як лікарів з низьким рівнем рефлексивності і креативності відрізняють нечітке усвідомлення життєвих цілей і цінностей, низька мотивація та самокерованість під час навчання i байдужість до результатів роботи, плин у потоці діяльності інших.

За даними нашого спостереження, до останнього типу особистостей можна віднести майже третину слухачів серед лікарів зі стажем роботи більше 5 років. Останні не виявляли мотивації до навчання у ділянках, які безпосередньо впливають на їхнє життєве становище, не проявляли допитливості і бажання зрозуміти глобальну концепцію та внутрішню логіку розвитку подій. Відчуття сенсу досягнення компетентності виконання навиків первинної реанімації вони досягали після багатьох повторних відпрацювань теми за контрольними листами виконання процедури за вимогою викладача та взаємодією зі слухачами, що ефективно виконували всі компоненти навиків з однієї-двох спроб. Позитивний вплив на досягнення компетентності всіма спеціалістами групи також дали обговорення після перегляду відеозаписів допущених помилок під час тренінгу та порівняння своїх вмінь із навчальним фільмом про належну організацію роботи для впровадження на робочому місці методики реанімації новонароджених у закладах країн із розвинутою медициною. Ключем до мотивації слухачів обох груп спостереження стали рівень активності навчального процесу та ефективність педагогів, котрі ще до початку навчання знали, які зміни в поведінці лікарів мають відбутися після закінчення циклу, та створили відповідні навчальні завдання і навчальне середовище на кафедрі.

Створення навчальної атмосфери для успішного засвоєння програми реанімації новонароджених. В епоху постіндустріальної освіти виникли корінні зміни та перетворення в політиці, економіці, культурі, умовах праці та особистому житті кожної людини. Перед системою освіти гостро стала проб- лема перебудови її мети та змісту, форм, методів, засобів організації відповідно до вимог часу [9], що позначилось на створенні навчального середовища і завдань до циклів удосконалення лікарів.

Навчальні завдання до тем програми первинної реанімації відповідають різним сферам: пізнавальній, афективній та психомоторній. Пізнавальні визначають зміну знань про фізіологію кардіореспіраторної адаптації та причини формування депресії новонароджених і способу мислення для досягнення умов належної медичної допомоги 3 метою попередження гіпоксично-ішемічних пошкоджень. Афективні - відповідають змінам почуттів і позицій лікаря, що навчається, після чого він буде більш впевнений у собі та результатах роботи. Психомоторні завдання пов’язані зі спроможністю особи фізично осягнути необхідний об’єм знань і вмінь та виконати програму первинної реанімації. Для цього в навчальні плани циклів внесені теми практичних занять з програми реанімації новонароджених у пологовій залі, підготовлені методичні розробки до них. Під час занять з інтернами та лікарями без стажу роботи наголос робили на самостійне вивчення матеріалу підручника і контроль його засвоєння пре-тестом для зарахування в групу; на викладання теоретичних основ теми з презентацією належного виконання програми реанімації новонароджених і демонстрацією навчального відеофільму. Знання матеріалу теми перевіряли тестовим контролем, позитивний результат якого був допуском для засвоєння практичних навиків.

Опрацювання навиків здійснювали в малих групах по 2-3 людини до ступеня “володіє” з відеозаписом виконання процедури та аналізом індивідуальних помилок, а також контролем за еталоном і листом виконання практичних навичок. В кінці заняття проводили екзамен на володіння практичними навиками реанімації новонароджених за контрольним листом виконання процедури. Використання розроблених або адаптованих нами контрольних листів виконання численних практичних навиків до тем даної програми навчання дозволяє провести негайну оцінку їх засвоєння та забезпечити таким чином зворотний зв'язок зі слухачами, ознайомити їх з реальною оцінкою їхніх знань та вмінь.

Неонатологам зі стажем пропонували вступний пре-тест для діагностики рівня підготовки і навчальних потреб, а потім давали стислий огляд теоретичної частини тем з демонстрацією належного виконання процедур, обговоренням у групі проблем щодо повноти впровадження і виконання 
програми реанімації новонароджених на своєму робочому місці. Опрацювання практичних навиків проводили за такою самою схемою, але з меншою тривалістю, бо лікарі мали певний досвід виконання необхідних навиків і процедур. Послідовність висвітлення викладачами теоретичних основ, демонстрації виконання та опанування навиками суворо відповідала вимогам програми реанімації, котра патентована і має численні свідчення ефективності, підтверджені оглядами Кохрейнівської бази рандомізованих наукових досліджень з доказовістю 1 А.

Ефективний педагог - керівник групи, який вміє організувати інтеграцію освіти та кар’єри слухачів, створити психолого-педагогічний супровід лікарів в освітньо-професійному просторі кафедри і вузу, а також володіє методами оптимізації педагогічного процесу, направленого на підтримання необхідних умов для самореалізації інтернів та лікарів зі стажем і формування конкурентоспроможної особистості. Викладач-інструктор повинен спланувати проведення і організувати вивчення теми таким чином, щоб максимально полегшити засвоєння матеріалу. При цьому серед факторів, що впливають на навчальний процес, одним із найпотужніших вважається уміння викладача контактувати зі слухачами. Ефективний викладач розуміє потреби лікарів і обирає стиль викладання, що відображає це розуміння. Учасникам створюються умови вільного спілкування. Аудиторія заохочується до запитань, коментарів, обговорення варіантів дії на робочому місці кожного слухача. При спілкуванні педагог постійно підтримує вербальний та невербальний контакт очима та жестами, своєю позою та місцем знаходження.

Сучасний викладач має свій бренд педагога-наставника (тьютора), визнаний спеціаліст у галузі медицини, яку викладає; вміє створювати навчальні модулі; ефективний тренер і менеджер, вміє працювати в команді та 3 командою; дипломований вчений, якому притаманне системне мислення, володіє дидактикою післядипломного навчання; може аналізувати та обробляти дані з різних модулів та проектів навчання, володіє предметом, який викладає на рівні фахівця експерт-класу; вміє слухати і бачити без оцінки, не пригнічує ініціативу слухача, але добивається очікуваного результату навчання залишаючись безкомпромісним до повноти та якості виконання програм з доказаною ефективністю; ефективний викладач - психолог, володіє техніками психологічних прийомів навчання; регулярно підвищує кваліфікацію, має моральні якості вчителя і культурної людини.

За нашим досвідом, обговорення матеріалу теми та спільне опанування навиків у невеликих групах командним методом у класі симуляційного навчання або безпосередньо на місці роботи слухачів у закладах родопомочі є найбільш ефективною формою проведення занять. Її використання забезпечує максимальну участь всіх слухачів і їх взаємодію 3 викладачем. Невелика аудиторія та ефективний викладач дозволяють проявити себе кожному слухачу при виконанні визначених навчальних завдань у психомоторній сфері, а також допомагає викладачу використати ефект інтерференції та реорганізації пам’яті при навчанні [10] і стимулювати пізнавальну та іншу корисну діяльність слухачів.

Симуляційне навчання дозволяє викладачу проводити розбір навчальних занять (дебрифінг) після “програвання сценарію” теми: візуалізація дій, виконаних під час симуляції; вільне самовираження учасників після емоційних моментів (як полегшення, так і невдоволення); самооцінка; оцінка групової динаміки; об’єктивніше оцінювати засвоєння та утримання отриманих знань.

Висновки. Досвід застосування моделювання клінічних ситуацій при симуляційному навчанні спеціалістів безпосередньо в закладах родопомочі дозволив підвищити ефективність навчального процесу і покращити показники роботи пологових будинків. Слухачі мають змогу отримати не лише теоретичну підготовку, а й в обов’ язковому порядку оволодіти необхідними практичними навичками i вмінням роботи, що сприяє поліпшенню розуміння та засвоєння матеріалу, набуття професійної компетентності виконати вимоги ILCOR 2015 року.

Для ефективного засвоєння програми первинної реанімації новонароджених медичним персоналом закладів родопомочі, регламентованих вимогами MO3 України алгоритмів надання реанімаційної допомоги доношеним і недоношеним дітям, необхідно впровадження методики безперервного навчання команд спеціалістів не рідше одного разу на 2 роки, а в проміжках проводити кожні 6 місяців короткі тренінги для тренерів, котрі навчатимуть колег у своїх закладах.

Викладання програми має проводити ефективний педагог з урахуванням сучасних вимог до навчання дорослих і відповідним матеріальним та методичним забезпеченням для симуляційного навчання.

Необхідними $є$ пошук та впровадження в навчальний процес спеціалістів нових методик для кращого оволодіння знаннями та вміннями, збереження отриманих знань та їх систематичного 
використання з метою поліпшення якості надання допомоги новонародженим.

Зважаючи на важливість проблеми, доцільно мати національний центр контролю виконання програми реанімації новонароджених, якості навчання спеціалістів та ефективності їх роботи після навчання.

6. Різник В. В. Методика професійного навчання : дидактичне проектування, основні технології навчання / В. В. Різник, Н. А. Різник. - URI: http://ephsheir.phdpu. edu.ua:8081/xmlui/handle/8989898989/1263.

7. Маркина Н. А. Рефлексивные механизмы креативности личности : автореф. дисс. на соискание уч. ст. канд. психол. наук / Н. А. Маркина. - М., 2012. - 23 с.

8. Прошин А. Т. Психофизиологические механизмы адаптивного поведения в стартл-ситуации : автореф. дисс. на соискание уч. ст. канд. психол. наук / А. Т. Прошин. - М., 2011. - 23 с.

9. Новиков А. М. Постиндустриальное образование : публицистическая полемическая монография / А. М. Новиков ; ред. Т. В. Новикова. - М. : Эгвес, 2008. -136 с.

10. Созинов А. А. Эффект интерференции и реорганизация памяти при научении : автореф. дисс. на соискание уч. ст. канд. психол. наук / А. А. Созинов. M., 2008.- 24 c.

Retrieved from: http://ephsheir.phdpu.edu.ua:8081/xmlui/ handle/8989898989/1263 [in Ukrainian].

7. Markina, N.A. (2012). Refleksivnyye mehanizmy kreativnosti lichnosti: avtoref. dis. na soiskanie uch. st. kand. psihologicheskih nauk [Reflexive mechanisms of personal creativity: abstract of candidate's thesis in psychological sciences]. Moscow [in Russian].

8. Proshin, A.T. (2011). Psihofiziologicheskiye mehanizmy adaptivnogo povedeniya $v$ startl-situacii: avtoref. dis. na soiskanie uch. st. kand. psihologicheskih nauk [Psychophysiological mechanisms of the adaptive behaviour in the startle situation: abstract of candidate's thesis in psychological sciences]. Moscow [in Russian].

9. Novikov, A.M., \& Novikova, T.V. (Ed.) (2008). Postindustrial'noye obrazovanie: publitsysticheskaya polemicheskaya monografiya [Post-industrial education: publicistic and polemical monography].-Moscow: EgvesJegves [in Russian].

10. Sozinov, A.A. (2008). Effekt interferentsyi $i$ reorganizatsyya pamyati pri nauchenii: avtoref. dis. na soiskanie uch. st. kand. psihologicheskih nauk [Interference effect and memory reorganizing in learning: abstract of candidate's thesis in psychological sciences]. Moscow [in Russian]. 